\title{
Meningkatan Kemampuan Pemecahan Masalah Matematis Menggunakan Strategi Problem Based Learning Berbantuan Mind Mapping
}

\author{
Ana Setiani, ${ }^{1, *}$, Hamidah Suryani Lukman ${ }^{2}$, Suningsih $^{3}$ \\ ${ }^{1,2}$ Universitas Muhammadiyah Sukabumi \\ ${ }^{3}$ SMA Muhammadiyah Sukabumi \\ *anasetiani361@ummi.ac.id
}

\begin{tabular}{|l|l|l|l|}
\hline Received : 02-06-2020 & Revised: $30-09-2020$ & Accepted: 22-10-2020 & Published: 05-12-2020 \\
\hline
\end{tabular}

\begin{abstract}
ABSTRAK
Penelitian ini bertujuan untuk mengetahui penggunaan strategi Problem Based Learning berbantuan Mind Mapping dapat meningkatkan kemampuan pemecahan masalah matematis siswa SMA Muhammadiyah Sukabumi tahun ajaran 2019/2020 pada pokok bahasan Statistika. Penelitian tindakan kelas ini dilakukan di kelas XII IPS Muhammadiyah Sukabumi. Pada siklus pertama pertama belum terlihat peningkatan, disebabkan karena siswa masih belum terbiasa menyelesaikan soal kemampuan pemecahan masalah matematis berbantuan Mind Mapping, sedangkan pada siklus II siswa mulai terbiasa menyelesaikan soal kemampuan pemecahan masalah matematis berbantuan Mind Mapping dengan baik. Terlihat dari hasil penelitian menunjukan adanya peningkatan terlihat dari rata-rata hasil tes sebesar 53,25 pada siklus I menjadi 72,37 pada siklus II. Hal tersebut bisa dilihat dari pecapaian aktivitas belajar siswa pada siklus I rata-rata sebesar 54,5, pada siklus II rata-rata sebesar 65,19. Dari hasil pelaksanaan siklus I dan siklus II bisa ditarik kesimpulan penggunaan strategi Problem Based Learning berbantuan Mind Mapping dapat meningkatkan kemampuan pemecahan masalah matematis siswa di SMA Muhammadiyah Sukabumi.
\end{abstract}

Kata Kunci : Problem Based Learning, Mind Mapping

\begin{abstract}
This study aims to determine the use of the Problem Based Learning strategy assisted by Mind Mapping to improve the mathematical problem solving skills of students of SMA Muhammadiyah Sukabumi in the 2019/2020 academic year on the subject of Statistics. This classroom action research was conducted in class XII IPS Muhammadiyah Sukabumi. In the first cycle there was no improvement, because students were still not used to solving problems with Mind Mapping assisted mathematical problem solving abilities, while in the second cycle students began to get used to solving problems with Mind Mapping assisted mathematical problem solving abilities properly. It can be seen from the results of the study that there is an increase seen from the average test result of 53.25 in the first cycle to 72.37 in the second cycle. This can be seen from the achievement of student learning activities in the first cycle an average of 54.5, in the second cycle an average of 65.19. From the results of the implementation of cycle I and cycle II, it can be concluded that the use of the Problem Based Learning strategy with the assistance of Mind Mapping can improve the mathematical problem solving skills of students at SMA Muhammadiyah Sukabumi.
\end{abstract}

Keywords: Problem Based Learning, Mind Mapping 


\section{PENDAHULUAN}

Matematika adalah salah satu mata pelajaran yang penting baik sebagai alat bantu, maupun sebagai pembimbing pola pikir maupun sebagai pembentuk sikap, maka dari itu matematika diharapkan dapat dikuasai oleh mahasiswa (Tsany, Septian, \& Komala, 2020). Bruner (Suherman, 2011) menyatakan bahwa belajar matematika akan lebih berhasil jika proses pengajaran diarahkan kepada konsep-konsep dan struktur-struktur yang terbuat dalam pokok bahasan yang diajarkan. Berdasarkan hasil wawancara dengan salah satu guru matematika SMA Muhammadiyah Sukabumi menyatakan bahwa: "Siswa mengalami kesulitan dalam menyelesaikan pemecahan masalah pada materi statistika, jika soal yang diberikan sedikit bervariasi maka siswa sulit mengerjakan soal tersebut". Hal ini disebabkan kurangnya menyelesaikan soal, kurangnya minat siswa dalam belajar matematika serta rendahnya kemampuan pemecahan masalah matematis siswa (Septian, 2017).

Sama halnya dengan hasil observasi awal di SMA Muhammadiyah Sukabumi khususnya kelas XII IPS yang berjumlah 20 siswa, terdiri 13 siswa putra dan 7 siswa putri kemampuan mengerjakan soal-soal sifatnya pemecahan masalah matematis masih relatif rendah. Hal ini terlihat dalam hal: 1) hasil tes kemampuan awal kemampuan pemecahan masalah matematik di KKM yaitu kisaran rata-rata (41,50\%). Akar penyebab rendahnya kemampuan pemeahan masalah matematis diantaranya adalah, siswa masih belum terbiasa mengerjakan soal-soal rutin, soal-soal cerita sifatnya harus memahami terlebih dahulu soal.

Berdasarkan fakta-fakta yang telah dikemukakan, hal ini menunjukkan bahwa kompetensi matematika terutama kemampuan pemecahan masalah matematis siswa masih rendah. Rendahnya kemampuan pemecahan masalah matematika siswa akan mempengaruhi kualitas belajar siswa yang akan berdampak pada rendahnya prestasi belajar siswa disekolah.

Hal yang dibutuhkan untuk mengatasi permasalahan tersebut, dalam pembelajaran matematika harus digunakan strategi pembelajaran yang sesuai. Sebagai alternatif, strategi pembelajaran yang diterapkan yaitu Problem Based Learning. Strategi Problem Based Learning merupakan strategi yang memungkinkan siswa berperan secara aktif dalam kegiatan pembelajaran (Amalia, Purwaningsih, Widodo, \& Fasha, 2020). Siswa dituntut untuk membuat catatan dan menyimpulkan sendiri dari permasalahan yang disampaikan oleh guru, dimana sebelumnya guru membuatkan skema atau pola dan berbatuan Mind Mapping yang bertujuan siswa dengan mudah memahami setiap materi yang akan 
dipelajari. Mind Mapping memiliki kelebihan yakni dapat memahami pokok masalah yang terjadi, sehingga dapat diambil cara untuk mengatasi permasalahan tersebut.

Pembelajaran dengan model Problem Based Learning dapat meningkatkan penguasaan konsep siswa sehingga akan berpengaruh positif terhadap kemampuan pemecahan masalah matematis siswa (Indriyana \& Tirta, 2017; Muhammad, Septian, \& Sofa, 2018). Model Problem Based Learning merupakan model pembelajaran yang menggunakan masalah kontekstual dalam pembelajarannya matematika (Fatwa, Septian, \& Inayah, 2019). Penggunaan strategi mind mapping telah mampu meningkatkan pemahaman konsep siswa sehingga dapat meningkatkan kemampuan pemecahan masalah matematis siswa (Monariska, 2017). Penggunaan Mind Mapping dalam fase Problem Based Learning sebagai hasil karya kegiatan diskusi penyelesaian masalah dapat memudahkan siswa mengorganisir dan memahami permasalahan yang disajikan. Penerapan teknik peta pikiran/Mind Mapping dapat meningkatkan penguasaan kompetensi dasar siswa dengan adanya hasil belajar yang lebih baik (Putra, 2012). Model pembelajaran Problem Based Learning lebih optimal jika dibantu dengan penggunaan strategi Mind Mapping. Sejalan juga, penggunaan model pembelajaran Problem Based Learning lebih optimal jika dibantu dengan penggunaan strategi Mind Mapping (Wardhani, Sunarno, \& Suparmi, 2012).

Berdasarkan penelitian yang dilakukan oleh Sarif Hidayat (2018) dengan judul "Upaya Meningkatkan Kemampuan Melakukan Operasi Hitung yang Melibatkan Berbagai bentuk Pecahan bagi Siswa Kelas V dengan Problem Based Learning”. Hasil penelitian menujukan bahwa denga Problem Based Learning dapat meningkatkan kemampuan operasi hitung dengan melibatkan berbagai bentuk pecahan, sedangkah pada hasil observasi aktivitas siswa terdapat peningkatan terhadap pembelajaran tersebut.

Sejalan juga dengan penelitian yang dilakukan oleh (Septian, 2017) dengan judul "Penerapan GeoGebra untuk Meningkatkan Kemampuan Pemecahan Masalah Matematis Mahasiswa Program Studi Pendidikan Matematika Universitas SuryaKancana”. Hasil penelitian menujukan peningkatan kemampuan pemecahan masalah matematis mahasiswa yang menerapkan GeoGebra lebih baik daripada mahasiswa yang menggunakan pembelajaran ekpsositori.

Begitu juga dengan penelitian yang sudah dilakukan oleh (Artika \& Karso, 2019) dengan judul "Meningkatkan Kemampuan Pemecahan Masalah Matematis Siswa dengan Menggunakan Metode Pembelajaran Thinking Aloud Pair Problem Solving”. Dengan hasil terdapat peningkatan kemampuan pemecahan masalah matematis siswa dengan menggunakan model Thinking Aloud Pair Problem Solving dibandingan dengan model 
pembelajaran biasa dan sikap positif siswa seteleh menggunakan model Thinking Aloud Pair Problem Solving.

Berdasarkan uraian diatas, permasalahan-permasalahan yang dihadapi oleh peneliti yang berkaitan dengan kondisi siwa-siswi yang ada di SMA Muhammadiyah Sukabumi, maka tujuan dalam penelitian ini adalah untuk meningkatkan kemampuan pemecahan masalah matematis siswa dan aktivitas belajar siswa dengan menggunakan strategi pembelajaran Problem Based Learning berbantuan Mind Mapping.

\section{METODE PENELITIAN}

Objek penelitian adalah siswa kelas XII IPS dengan jumlah siswa 16 orang semester Genap tahun ajaran 2019/2020 dengan kompetensi dasar ukuran gejala pusat dan ukuran gejala letak.

Penelitian Tindakan Kelas dilaksanakan sebanyak dua siklus, dengan tujuan untuk melihat perkembangan hasil belajar siswa dan aktivitas pembelajaran siswa dalam mengikuti pembelajaran matematika dengan strategi Problem Based Learning berbantuan Mind Mapping. Adapun jadwal penelitian yang telah ditentukan dari sekolah. Siklus I dan siklus II terdiri dari Perencanaan, Pelaksanaan, Pengamatan, dan Refleksi. Tahapan Penelitian Tindakan Kelas dilaksanakan yang saya gunakan diadopsi dari Kemmis \& Taggart (Wirani, 2018).

Instrumen yang digunakan yaitu tes tulis kemampuan pemecaha masalah matematis siswa dan lembar observasi. Teknik alanisis dilakukan secara sederdaha yaitu dengan membandingkan rata-rata dan persentase hasil tes dan observasi.

\section{HASIL DAN PEMBAHASAN}

\section{Observasi Aktivitas Siklus I dan Siklus 2}

Hasil observasi aktivitas belajar siswa pada siklus I dan siklus II dapat dilihat pada Gambar 1.

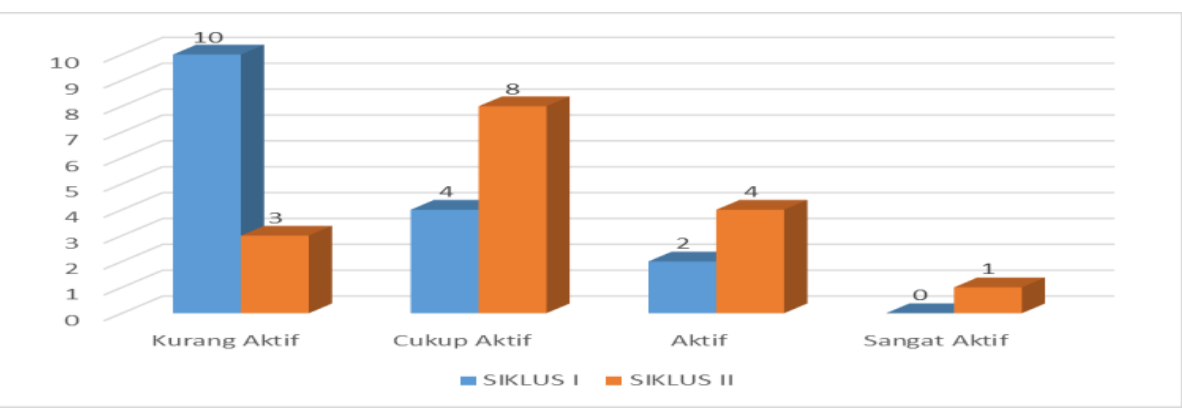

Gambar 1. Perbandingan Aktivitas Belajar Siklus I dan Siklus II 
Berdasarkan Gambar 2, data aktivitas belajar siswa siklus I diketahui tedapat 10 orang siswa $(62,5 \%)$ dari 16 siswa termasuk kategori kurang aktif, 4 siswa $(25 \%)$ dari 16 siswa termasuk kategori cukup aktif, dan 2 siswa (12,5\%) dari 16 siswa termasuk kategori aktif. Perhitungan tersebut menujukan persentase siswa yang memiliki keaktivan belajar masik kurang aktif. Sedangkan rata-rata keaktivan belajar siswa pada siklus I 54,5 termasuk pada kategori kurang aktif.

Data aktivitas belajar siswa siklus II diketahui tedapat 6 orang siswa $(18,75 \%)$ dari 16 siswa termasuk kategori kurang aktif, 8 siswa (50\%) dari 16 siswa termasuk kategori cukup aktif, dan 4 siswa (25\%) dari 16 siswa termasuk kategori aktif, dan 1 siswa $(6,25 \%)$ dari 16 siswa termasuk kategori sangat aktif. Perhitungan tersebut menujukan persentase siswa yang memiliki keaktivan belajar cukup aktif. Sedangkan rata-rata keaktivan belajar siswa pada siklus II 71,88, termasuk pada kategori cukup aktif.

Keaktifan siswa dalam pembelajaran terjadi karena guru menyampaikan materi dengan model pembelajaran dengan baik. Perbaikan terus dilakukan dalam rangka memperbaiki cara mengajar, kualitas mengajar, dan proses belajar (Soleh, Setiawan, \& Haqi, 2020; Suryawan \& Permana, 2020). Peningkatkan aktivitas siswa terjadi karena dalam proses Problem Based Learning berbantuan Mind Mapping terjadi proses diskusi antara siswa dengan siswa dan siswa dengan guru (Kusumawardani, Wardono, \& Kartono, 2018; Setyansah \& Suprapto, 2017). Terjadinya diskusi ini menyebabkan peningkatan aktifitas dalam diskusi, komunikasi, presentasi siswa (Soleh et al., 2020; Supriadi, 2015).

Hal ini sejalan dengan beberapa penelitian sebelumnya yang menyatakan bahwa aktifitas siswa akan meningkat dalam pembelajaran akibat model pembelajaran yang digunakan efektif dan efisien (Kusumawardani et al., 2018; Monariska, 2018; Suwarman, 2017). Selain itu, dampak positif dari model atau pendekatan pembelajaran tersebut sangat baik.

\section{Hasil Belajar Siklus I dan Siklus II}

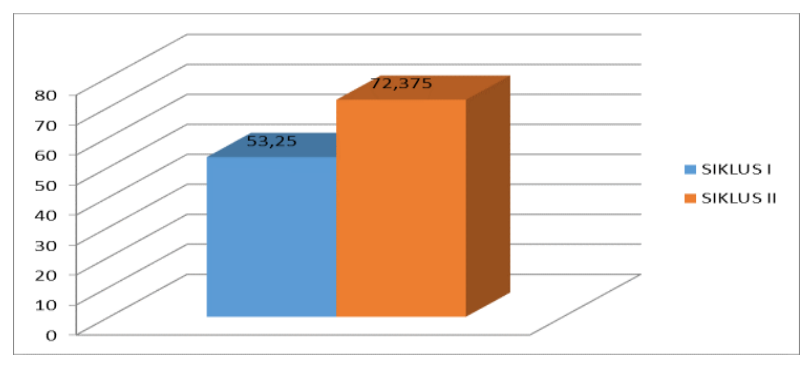

Gambar 2. Perbandingan Rata-Rata Nilai Siklus I dan Siklus II 
Berdasarkan Gambar 2, hasil pembelajaan yang telah dilaksanakan pada siklus I dan siklus II terlihat perbedaannya. Hasil belajar siklus rata-rata 53,25 dengan persentase siswa yang mencapai KKM Cuma 25\%, selanjutnya diperbaiki pada proses pembelajaran pada siklus II rata-rata terdapat peningkatan menjadi 72,37 dengan persentase siswa yang mencapai KKM menjadi $75 \%$.

Berdasarkan hasil pembelajaran yang telah dilakukan menggunakan strategi Problem Based Learning berbantuan Mind Mapping, maka dapat disimpulkan bahwa proses pembelajaran mulai dari siklus I dan siklus II sudah dikatakan meningkat dari target sebelumnya dan dapat dikatakan sudah berhasil. Kekurangan dan kendala pada proses pembelajaran sebelumnya sudah dapat teratasi oleh peneliti.

Peningkatkan hasil belajar dari siklus I ke siklus II terjadi karena siswa merasa senang dan tertarik dengan pembelajaran yang berlangsung, terjadi komunikasi dua arah antara siswa dengan siswa dan siswa dengan guru (Nasution \& Ahmad, 2018; Soleh et al., 2020). Materi yang diberikan oleh guru difahami oleh siswa. Guru sudah memperbaiki apa yang menjadi bahan refleksi ketika melakukan pembelajaran di siklus I, sehingga hasil yang diperoleh sudah maksimal (Suwarto \& Purnami, 2018).

Berdasarkan beberapa penelitian sebelumnya, model pembelajaran yang berpusat pada siswa dapat meningkatkan hasil belajar siswa (Junedi \& Sari, 2020; Septian, Darhim, \& Prabawanto, 2020; Supriadi, 2015; Suryawan \& Permana, 2020; Suwarto \& Purnami, 2018). Strategi Problem Based Learning berbantuan Mind Mapping juga secara khusus dapat meningkatkan hasil belajar siswa. Mind mapping membuat siswa lebih memahami materi karena mudah diterapkan dalam pemebelajaran sehari-hari. Adapun kasus yang diberikan memberikan keleluasaan pada siswa dalam berpendapat dan merangkum materi dengan mind mapping.

\section{KESIMPULAN}

Berdasarkan hasil dari penelitian tindakan kelas yang telah dilaksanakan untuk mencapai tujuan penelitian dan rumusan masalah, maka dapat ditarik kesimpulan yaitu aktivitas belajar siswa mengalami peningkatan dan terjadi peningkatan pemahaman kemampuan pemecahan masalah matematis siswa.

\section{REFERENSI}

Amalia, S. R., Purwaningsih, D., Widodo, A. N. A., \& Fasha, E. F. (2020). Model Problem Based Learning Berbantuan GeoGebra dan Model Realistic Mathematics Education 
terhadap Representasi Matematis Siswa ditinjau dari Gaya Kognitif. Jurnal Elemen, 6(2), 157-166. https://doi.org/10.29408/jel.v6i2.1692

Artika, T., \& Karso, K. (2019). Meningkatkan Kemampuan Pemecahan Masalah Matematis Siswa Dengan Menggunakan Metode Pembelajaran Thinking Aloud Pair Problem Solving (Tapps). Prisma, 8(2), 191-200. https://doi.org/10.35194/jp.v8i2.791

Fatwa, V. C., Septian, A., \& Inayah, S. (2019). Kemampuan Literasi Matematis Siswa melalui Model Pembelajaran Problem Based Instruction. Mosharafa: Jurnal Pendidikan Matematika, 8(3), 389-398.

Indriyana, E., \& Tirta, S. I. M. (2017). The Students' Thinking Process on Mathematics Problem Solving Through Scaffolding. The International Journal of Social Sciences and Humanities Invention, 4(8), 3774-3782.

Junedi, B., \& Sari, E. P. (2020). Penggunaan Multimedia Pembelajaran Interaktif terhadap Kemampuan Koneksi Matematis Siswa Kelas XI MIPA SMA. Prisma, 9(1), 87. https://doi.org/10.35194/jp.v9i1.915

Kusumawardani, D. R., Wardono, \& Kartono. (2018). Pentingnya Penalaran Matematika dalam Meningkatkan Kemampuan Literasi Matematika. Prisma, 1(1), 588-595.

Monariska, E. (2017). Penerapan Metode Mind Mapping untuk Meningkatkan Kemampuan Pemahaman Konsep Matematis Mahasiswa pada Mata Kuliah Kalkulus I. PRISMA, 6(1), 17-31. https://doi.org/10.35194/jp.v6i1.25

Monariska, E. (2018). Upaya Meningkatkan Kemampuan Penalaran Matematis Siswa Smk Melalui Pembelajaran Kooperatif Tipe Numbered Head Together. Prisma, 7(2), 217. https://doi.org/10.35194/jp.v7i2.531

Muhammad, G. M., Septian, A., \& Sofa, M. I. (2018). Penggunaan Model Pembelajaran Creative Problem Solving untuk Meningkatkan Kemampuan Pemecahan Masalah Matematis Siswa. Mosharafa: Jurnal Pendidikan Matematika, 7(3), 315-326. https://doi.org/10.31980/mosharafa.v7i3.140

Nasution, D. P., \& Ahmad, M. (2018). Penerapan Pembelajaran Matematika Realistik untuk Meningkatkan Kemampuan Komunikasi Matematis Siswa. Mosharafa: Jurnal Pendidikan Matematika, 7(3), 389-400. https://doi.org/10.31980/mosharafa.v7i3.133

Putra, P. P. (2012). The Use of Mind Mapping Strategy in the Teaching of Writing at SMAN 3 Bengkulu, Indonesia Riswanto State Institute of Islamic Studies (IAIN) Bengkulu, Indonesia. International Journal of Humanities and Social Science, 2(21), 60-68. Retrieved from www.ijhssnet.com

Septian, A. (2017). Penerapan Geogebra untuk Meningkatkan Kemampuan Pemecahan Masalah Matematis Mahasiswa Program Studi Pendidikan Matematika Universitas Suryakancana. PRISMA, 6(2). https://doi.org/10.35194/jp.v6i2.212

Septian, A., Darhim, \& Prabawanto, S. (2020). Mathematical representation ability through geogebra-assisted project-based learning models. Journal of Physics : Conference Series, 1657(1), 12019. https://doi.org/10.1088/1742-6596/1657/1/012019

Setyansah, R. K., \& Suprapto, E. (2017). Peningkatan Kemandirian Belajar Mahasiswa Melalui Pembelajaran Berbasis E-Learning Pada Mata Kuliah Kalkulus Differensial. APOTEMA: Jurnal Program Studi Pendidikan Matematika, 3(2), 78-90. https://doi.org/10.31597/ja.v3i2.144

Soleh, E. R. A., Setiawan, W., \& Haqi, R. (2020). Upaya Meningkatkan Kemampuan Komunikasi Matematis dan Aktivitas Belajar Siswa Menggunakan Model Problem Based Learning. Prisma, 9(1), 1. https://doi.org/10.35194/jp.v9i1.798

Suherman, E. dkk. (2011). Strategi Pembelajaran Matematika Kontemporer. Bandung: PT Remaja Rosdakarya, 133, 31-59. https://doi.org/10.1016/j.proeng.2015.12.621

Supriadi, N. (2015). Pembelajaran Geometri Berbasis Geogebra Sebagai Upaya 
Meningkatkan Kemampuan Komunikasi Matematis. Al-Jabar: Jurnal Pendidikan Matematika, 6(2), 99-109. $\quad$ Retrieved from http://ejournal.upi.edu/index.php/jpmanper/article/view/00000\%0AImpak

Suryawan, I. P. P., \& Permana, D. (2020). Media Pembelajaran Online Berbasis Geogebra sebagai Upaya Meningkatkan Pemahaman Konsep Matematika. Prisma, 9(1), 108. https://doi.org/10.35194/jp.v9i1.929

Suwarman, R. F. (2017). Pengaruh Model Pembelajaran Auditory, Intellectually, Repetition (AIR) terhadap Peningkatan Pemecahan Masalah Matematis Siswa. PRISMA, 6(2). https://doi.org/10.35194/jp.v6i2.58

Suwarto, S., \& Purnami, A. S. (2018). Upaya Meningkatkan Pemahaman Konsep Matematika Melalui Hypothetical Learning Trajectory Pada Materi Vektor. IndoMath: Indonesia Mathematics Education, $\quad$ 1(2), 69. https://doi.org/10.30738/indomath.v1i2.2614

Tsany, U. N., Septian, A., \& Komala, E. (2020). The ability of understanding mathematical concept and self-regulated learning using macromedia flash professional 8. Journal of Physics: Conference Series, 1657, 12074. https://doi.org/10.1088/17426596/1657/1/012074

Wardhani, K., Sunarno, W., \& Suparmi, S. (2012). Pembelajaran Fisika Dengan Model Problem Based Learning Menggunakan Multimedia Dan Modul Ditinjau Dari Kemampuan Berpikir Abstrak Dan Kemampuan Verbal Siswa. Jurnal Inkuiri, 1(2), 163-168.

Wirani, E. W. (2018). Penelitian Kuantitatif, Kualitatif dan Penelitian Tindakan Kelas. In Penelitian Kuantitatif, Kualitatif dan Penelitian Tindakan Kelas. 